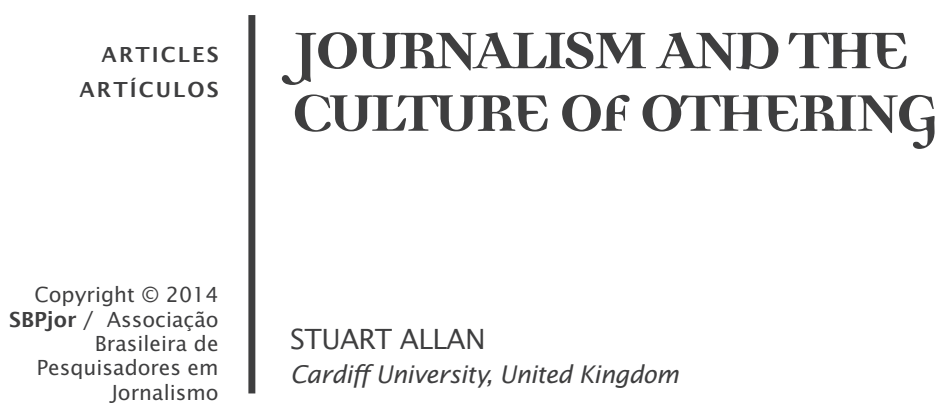

ABSTRACT - In seeking to render problematic traditional conceptions of journalistic identity, this article critiques the seemingly natural, even 'common sensical' structures of social exclusion recurrently underpinning its formulation. More specifically, it explores, firstly, a series of insights provided by feminist and gender-sensitive critiques of journalism. In assessing the typically subtle imperatives of sexism in news reporting, it considers the extent to which journalistic identity continues to be defined within the day-to-day 'macho culture' of the newsroom, where female journalists' perceptions of sexual discrimination typically vary sharply from those held by their male colleagues. Secondly, attention turns to the issue of ethnic diversity, where the need to deconstruct the racialised projection of 'us and them' dichotomies precisely as they are taken-up and re-inflected in news reporting is shown to be of pressing concern. In bringing together these respective set of debates, primarily from British and US contexts, this article aims to contribute to conceptual efforts to further unravel the ways in which journalists' routine, everyday choices about what to report - how best to do it, and why -involves them in a politics of mediation, one where all too often a culture of othering proves significant.

Keywords: Journalism. Identity. Professionalism. Sexism. Racism. Othering.

\title{
JORNALISMO E A CULTURA DA ALTERIDADE
}

RESUMO - Ao procurar problematizar as concepções tradicionais da identidade jornalística, este artigo oferece uma crítica às estruturas aparentemente naturais, até mesmo "do senso comum", sobre a exclusão social, que atualmente sustentam a sua formulação. Em primeiro lugar, e mais especificamente, explora uma série de insights fornecidos por feministas e por perspectivas críticas de estudos de gênero ao jornalismo. Ao avaliar os imperativos tipicamente sutis do sexismo presentes nos relatos noticiosos, ele sugere que a identidade jornalística continua a ser definida pela "cultura machista" no cotidiano da redação, onde as percepções da discriminação sexual das jornalistas do sexo feminino costumam variar acentuadamente em relação às realizadas por seus colegas do sexo masculino. Em segundo lugar, o texto foca a questão da diversidade étnica, em que a necessidade de desconstruir a projeção racista das dicotomias "nós e eles", exatamente como assumidas e refletidas nos relatos das notícias, revela-se como uma preocupação urgente. Ao juntar estes respectivos conjuntos de debates, principalmente de contextos britânicos e norte-americanos, este artigo visa contribuir com esforços conceituais para esclarecer ainda mais as maneiras pelas quais as escolhas rotineiras e cotidianas dos jornalistas com relação àquilo que é para relatar - qual a melhor maneira de fazê-lo, e por que - os envolvem numa política de mediação, na qual uma cultura de alteridade se mostra muitas vezes significativa. Palavras-chave: Jornalismo.Identidade. Profissionalismo. Sexismo. Racismo. Alteridade. 


\section{EL PERIODISMO Y LA CULTURA DE LA ALTERIDAD}

RESUMEN - El objetivo de este artículo es problematizar las concepciones tradicionales de la identidad periodística. Con ello se plantea una crítica a las estructuras aparentemente naturales, incluso de "sentido común", sobre la exclusión social que actualmente sustentan su formulación. En primer lugar, y de modo más específico, explora una de serie de percepciones proporcionadas por feministas y por perspectivas críticas de estudios de género en periodismo. La evaluación de los imperativos típicamente sutiles del sexismo presentes en los relatos noticiosos sugiere que la identidad periodística continúa siendo definida por la "cultura machista" en la cotidianidad de la redacción, donde las periodistas y sus colegas se sexo masculino suelen percibir de forma muy diferente la discriminación sexual. En segundo lugar, el texto se centra en la cuestión de la diversidad étnica, en la cual la necesidad de deconstruir la proyección racista de las dicotomías "nosotros y ellos", exactamente como se asumen y reflejan en los relatos de noticias, se revela como una preocupación urgente. Al reunir los respectivos conjuntos de debates, la mayoría de contextos británicos y norteamericanos, este artículo se propone contribuir con esfuerzos conceptuales para esclarecer aún más las maneras en las que las elecciones rutinarias y cotidianas de los periodistas con relación a aquello que hay que relatar — cuál es la mejor manera de hacerlo y por qué-, los involucran en una política de mediación en la cual una cultura de alteridad se muestra muchas veces significativa. Palabras clave: Periodismo. Identidad. Profesionalismo. Sexismo. Racismo. Alteridad.

\section{INTRODUCTION}

In a letter to one of his editors, the American newspaper proprietor Joseph Pulitzer - famous today for the prizes awarded for excellence in journalism bearing his name - offered his thoughts regarding how best to ensure the newspaper served its community of readers. One particularly noteworthy passage stated:

[E]very issue of the paper presents an opportunity and duty to say something courageous and true; to rise above the mediocre and conventional; to say something that will command the respect of the intelligent, the educated, the independent part of the community; to rise above fear of partisanship and fear of popular prejudice (apud SEITZ, 1924, p.286; see also IRELAND, 1938).

The letter, sent to George S. Johns of the Post-Dispatch on 10 August 1906, evoked an ideal of public service in elegant terms. On the occasion of Pulitzer's death in October 1911 , this vision - together with opinions about the relative extent to which it was realised figured in several assessments of his life's work as well as the impact of his newspapers in shaping the 'new journalism' of the era. In 
September the following year, thanks to his beneficence (namely, an endowment of $\$ 2$ million), the first cohort of students arrived to attend their first day of classes in the School of Journalism at Columbia University in New York (BOYLAN, 2003). Pulitzer's motivation to help underwrite the costs of the new programme was directly informed by his desire to secure the basis for a radically different conception of professional identity to be sustained. At stake, in his opinion, was nothing less than the very future of democratic life.

In contrast with the legal or medical professions, which adopted strict procedures of entry, licensed codes of ethics, and formal methods of self-regulation, no such measures were thought to be consistent with the practice of journalism envisaged for Columbia's future graduates. Certainly it was Pulitzer's (1904) steadfast belief, however, that journalism's status - that is to say, its elevation in the eyes of readers, as well as for journalists themselves - nonetheless deserved equal recognition. Professionalism, in every sense of the term, was to provide the guiding ethos to which all journalists should properly aspire. The factors shaping identity formation were to revolve around a declared commitment to the virtues of public-spiritedness. Precisely what the attendant 'standard of civic righteousness' envisaged by Pulitzer would entail defied easy elucidation, finding only a broad definition in relation to the 'character' necessary to advance the 'public good' instead. Moral courage, so vital for public service, would have to be taught - an aptitude for its principles, and with it the determination to behave responsibly, was not inborn. Here it is Pulitzer's distinction between 'real journalists' and 'men [and women] who do a kind of newspaper work that requires neither knowledge nor conviction' that underscored the difference between the personal qualities to be engendered by journalism education and those derived from 'mere business training' (PULITZER, 1904, p. 19). To be cultivated, at all costs, was a 'pride in the profession,' for the journalist alone 'has the privilege of moulding the opinion, touching the hearts and appealing to the reason of hundreds of thousands every day.' Every day, he added, 'opens new doors for the journalist who holds the confidence of the community and has the capacity to address it' (Ibid, p. 12).

Viewed from the vantage point of today, Pulitzer's bold assessment of the normative criteria shaping his preferred configuration of journalistic identity helps to illuminate some of the taken-for-granted assumptions informing current journalists' role perceptions. A certain mythology exists which celebrates 
this aspiration to democratic ideals (ranging from claims made by advocacy organisations to fictional portrayals of journalism in the entertainment media, and beyond), despite the recurrent scepticism expressed by many journalists themselves where such 'visions' of their craft are concerned (ALLAN, 2010a, 2010b; in a Brazilian context, see DE ALBUGUERQUE, 2005; HERSCOVITZ, 2004; MARQUES DE MELO, 2009; MARTINEZ, 2008). More often than not, however, these familiar discourses of identity, when read against the grain, reveal their dependence upon normalised structures of social exclusion warranting careful analysis.

Accordingly, in seeking to identify and critique these seemingly natural, even 'common sensical' structures, this article will explore, firstly, a series of insights provided by feminist and gender-sensitive critiques of journalism. In assessing the typically subtle imperatives of sexism in news reporting, it will be shown that important insights may be gained into the gendered dynamics of what is often described as a 'macho culture' in the newsroom. Secondly, attention turns to the issue of ethnic diversity, where the need to deconstruct the racialised projection of 'us and them' dichotomies precisely as they are taken-up and re-inflected in news reporting is shown to be of pressing concern. In bringing together these respective set of debates, primarily from British and US contexts, this article aims to contribute to conceptual efforts to further unravel the ways in which journalists' routine, everyday choices about what to report - how best to do it, and why -involves them in a politics of mediation, one where all too often a culture of othering proves significant.

\section{SEXISM AND JOURNALISM}

The problem of sexism, several historical accounts suggest, may be discerned from the earliest days of journalism, which is hardly surprising (CHAMBERS, STEINER and FLEMING, 2004). Flash forward to a more recent scene in Washington DC in January 2007, however, when White House officials invited network and cable anchors, together with the Sunday political show hosts, to a meeting with senior Bush administration officials to discuss the war in Iraq. CBS News's Katie Couric (2007) later recalled feeling that the meeting was 'a little disconcerting' when she realised - looking around the room - that something was wrong. 
I couldn't help but notice, despite how far we've come, that I was still the only woman there. Well, there was some female support staff near the door. But of the people at the table, the 'principals' in the meeting, I was the only one wearing a skirt. Everyone was gracious, though the jocular atmosphere was palpable.

The feminist movement that began in the 1970's helped women make tremendous strides - but there still haven't been enough great leaps for womankind. [...] That meeting was a reality check for me - and not just about Iraq. It was a reminder that all of us still have an obligation to ask: Don't more women deserve a place at the table too? (COURIC, 2007).

Today the day-to-day news culture of most newspaper and broadcast organizations is still being defined in predominantly male terms. While there has been a dramatic increase in the number of women securing jobs in journalism, white middle-class men continue to occupy the vast majority of positions of power throughout the sector. Women are still not being promoted to senior decision-making posts in proportion to the overall role they play in the profession. At a time when news organizations are facing ever-more intensive (and increasingly globalized) forms of competition, the costs of this failure to treat women fairly in the journalistic workplace continue to mount.

Several feminist researchers contend that while the success of high-profile women journalists - such as Couric, mentioned above - has gone a considerable distance toward breaking down the barriers to gender equality, they nonetheless remain stubbornly intact (CARTER, BRANSTON and ALLAN, 1998; CHAMBERS, STEINER and FLEMING, 2004; DE BRUIN and ROSS, 2004; EVERBACH, 2006; NORTH, 2009). A recent survey conducted by the American Society of Newspaper Editors (ASNE), for example, found that men continue to outnumber women in full-time daily newspaper positions by a 63 percent to 37 percent margin (ASNE, 2008). The same study found that minority women accounted for 17.16 of female newsroom staffers, thereby revealing a further dimension to institutionalized inequalities. Studies of British news organizations consistently show that the vast majority of senior journalists and editorial decision makers are men, with most estimates placing the number at higher than 80 per cent. Recent research conducted by the Sutton Trust (2006), for example, indicates that the "proportion of women among the top 100 news journalists increased from 10 per cent in 1986 to 18 per cent in 2006' (see also CHRISTMAS 1997; WOMEN IN JOURNALISM 1998). 'White, middle-class males have had it all their own way at the BBC since the days of Lord Reith and it is frankly amazing the extent to which they still have it their own way in the new millennium,' former 
BBC newsreader Anna Ford recently stated (apud WALKER, 2008). Journalist Glender Cooper (2008) reaffirms this view with reference to her own experience. When she joined the BBC in 2002, she recalls, 'I was taken aside by an editor (another white, middle-class man so ground down by the system that he was promoted soon afterwards) and given advice on how to succeed as a serious news journalist.' He suggested, she adds, "straightening my naturally curly hair to look more "authoritative". He also expressed regret that my eyes looked too big on screen' (COOPER, 2008).

The factors involved are complex, as Aldridge (2001) points out on the basis of her study involving interviews with women working in the UK regional press, but appear to revolve around status hierarchies founded on 'hard news' experience. What may appear to be deep-seated beliefs in a meritocracy based on performance, her findings suggest, would be better explained in terms of structural barriers to advancement:

\begin{abstract}
In newspapers, it is constantly affirmed, you are only as good as your most recent work, yet this logic of performativity is not followed through. To reach a position of influence you do not only need to demonstrate current skills and abilities but specific past experience, crucially a senior post related to breaking hard news. Full-time jobs in core news-related functions are almost impossible to combine with primary responsibility for dependants: '...in the whole of our newsroom [women] who have children and are still newsgatherers ...I can't think of any ...' (senior reporter, 25 , city evening paper). [...] When my respondents talked about their own lives and prospects, or recounted the difficulties of women colleagues, the constantly recurring theme was the hours of work - not just long, but unsocial, or unpredictable, or all three - characteristic of a ruthlessly profit-driven enterprise framed around the 'newsday' (ALDRIDGE, 2001).
\end{abstract}

Similar patterns are evident in the news organizations of other countries. Robinson (2005) examines the impact of the 'glass ceiling' on women's advancement in Canadian newsrooms, where equity legislation - helpful in securing women employment - has not had the desired effect where promotion is concerned. McGregor (2006) describes what he calls the 'pervasive power of man-made news' in New Zealand's news media. While little progress has been made by women at the editorship level, she argues, matters are improving for senior women just below that level. Djerf-Pierre (2007) points out that in Sweden, even though women were making up fifty percent of the profession by 2005 , journalism remains a 'male-dominated' field. There is a 'gender logic' shaping definitions of status, prestige and 
power, her research contends, one that works to align masculinity with 'ideas about what constitutes good journalism' (DJERF-PIERRE, 2007, p. 99).

Research conducted by the Project for Excellence in Journalism (PEW) offers quantitative data to support this line of critique. Drawing on findings from an examination of some 16,800 news stories across 45 different US news outlets (16 newspapers, four nightly newscasts, three network morning shows, nine cable programs, and nine internet news sites) during 20 randomly selected days over a nine month period in 2004, researchers discovered that men are called upon as news sources more than twice as often as women. 'More than three quarters of all stories contain male sources, while only a third of stories contain even a single female source' (PEW, 2005 , p. 2). The Report found, a disparity that was upheld across of the different news media under scrutiny. Further findings included:

\footnotetext{
* In every topic category, the majority of stories cited at least one male source.

* In contrast, the only topic category where women crossed the $50 \%$ threshold was lifestyle stories.

* The subject women were least likely to be cited on was foreign affairs.

* Newspapers were the most likely of the media studied to cite at least one female source in a story (41\% of stories). Cable news, despite all the time it has to fill, was the least likely medium to cite a female source (19\% of stories), and this held true across all three major cable channels.

* On network TV, the morning news programs, which often cover lighter fare, relied more on female sources. The evening newscasts were somewhat less likely, but still did so more than cable.

* The sports section of the newspaper stood out in particular as a male bastion. A mere $14 \%$ of stories on the front page of the sports section cited a woman, versus $86 \%$ that contained at least one male source. (PEW, 2005, p. 2-3)
}

When set in relation to US society in general, where women at the time made up 52 percent of the population (and about 47 percent of the employed civilian workforce) at the time, this disparity is all the more telling. Here the researchers caution that there is no implied suggestion that journalists should seek to achieve a balance between genders in every news story. That said, their conclusions do lead them to suggest that steps need to be taken to 'create more opportunity for female voices to emerge,' and urgently so (PEW, 2005, p. 17; see also CANN and MOHR's, 2001 similar findings for television news in Australia; and BECKER and DE BUSTAMANTE, 2009 for professionalism in Brazilian television news). 
In light of issues such as these, then, it is apparent that these norms of reportage need to be contextualized in relation to longstanding institutional power differentials within the journalistic workplace (where they tend to be all too readily defended with reference to a work ethos consistent with masculinized 'traditions' and 'customs'). Most newsrooms appear to be characterized by a gendered division between 'hard' news (such as economics, politics, government and crime) reporters, who tend to be men, and 'features' reporters, who are more likely, at least in relative terms, to be women. This division, far from correlating with the 'natural competencies' of individual male and female reporters ('men are better suited for the cut-and-thrust of hard news'), is frequently indicative of a sexual division of labour in the journalist's own household. Female reporters are more likely to experience a 'double-day' of work, one where they perform a disproportionate share of domestic (especially child care) responsibilities, than do their 'more professionally committed' male colleagues. These forms of labour are somewhat easier to manage in relation to the more regularized, structured and predictable hours associated with features reporting. As a result, 'prestigious areas of news production remain largely dominated by men,' Chambers and Steiner (2010, p. 49) write, 'particularly the high-status category of politics, as well as business, and sport'.

For these and related reasons, then, it becomes increasingly apparent why masculinised norms of professional identity have been so difficult to recast, despite the inroads female journalists are increasingly making in what has been perceived to be a male enclave for so many years.

\section{ETHNIC DIVERSITY AND JOURNALISM}

In the days leading up to the inauguration of Barack Obama as President of the United States, the issue of racism was generating considerable attention in press commentary for obvious reasons. Few news organizations were attending to their own shortcomings over the years, however, preferring to focus on examples of racial discrimination evidenced in other social institutions instead. One exception was the Meridian Star, a Mississippi newspaper, which published an apology for its past reporting of civil rights issues. In an editorial, 'We honour and we apologize,' it described the efforts of those in East Mississippi who played an integral role in the movement 
for equality. Its closing paragraphs read:

\begin{abstract}
There was a time when this newspaper - and many others across the south - acted with gross neglect by largely ignoring the unfairness of segregated schools, buses, restaurants, washrooms, theatres and other public places.

We did it through omission, by not recording for our readers many of the most important civil rights activities that happened in our midst, including protests and sit-ins. That was wrong. We should have loudly protested segregation and the efforts to block voter registration of black East Mississippians.

Current management understands while we can't go back and undo some past wrongs, we can offer our sincere apology and promise never again to neglect our responsibility to inform you, our readers, about the human rights and dignity every individual is entitled to in America - no matter their religion, their ethnic background or the color of their skin. (MERIDIAN STAR, 2009, Editorial)
\end{abstract}

This apology for 'gross neglect' attracted headlines in its own right, quite possibly - one hopes - encouraging other news organizations to revisit their own past coverage with a critical eye to their complicity in normalizing prejudice. If for some African American observers in the blogosphere the Meridian Star apology was a matter of 'better late than never,' for others it represented merely a first step that needed to be followed-up swiftly with concrete action.

Statistics produced by the American Society of Newspaper Editors (ASNE) underline the significance of this point. In a recent census of the industry (initiated as an annual exercise following the Kerner Commission report of 1968), it was found that the percentage of ethnic minority journalists working at daily newspapers in the US grew minimally in 2007 - specifically, from 13.43 percent of all such journalists to 13.52 percent of 52,600 full-time journalists. ASNE President Gilbert Bailon contextualised this data:

\footnotetext{
The numbers represent a dual reality: It's mildly encouraging that the minority percentage held steady despite difficult economic times that are causing many cutbacks. On the other hand, the total number of minority journalists employed at daily newspapers declined by nearly 300 people, which follows the pattern for the overall newsroom workforce. Such a trend will not help newspapers in their quest to reach parity with the minority population by 2025. (ASNE, 2008)
}

Here it is worth noting that 423 of the newspapers responding to the ASNE survey recorded that they had no minorities on their fulltime staff (the majority of these papers having circulations of 10,000 copies or less). This when 'a generic, monochromatic newsroom' - to use Bailon's phrase - will be unable to adequately serve its community 
of readers. To the extent this problem is being further exacerbated by the financial crises, it becomes all the more important to urge managers not to relinquish their commitment to improvements. 'Diversity is not a luxury or a fad,' the National Association of Black Journalists (NABJ) observes. 'It is a necessity for telling balanced news stories about America and for putting a fresh story perspective before the readers through the lens of minority journalists' (NABJ, 2008).

While there are grounds for cautious optimism that matters are improving, much work remains to be done. A report commissioned by the Greater London Authority (GLA) to investigate British print media coverage of Muslims and Islam from mid-2006 to mid-2007 makes this point all too apparent. While some examples of good practice were in evidence (such as 'one-off news items, features, projects and investigative articles'), they were found to be exceptions to the general rule. Much more typical were news reports depicting a basic antagonism between the West and Islam, with Muslims portrayed as 'a threat to traditional British customs, values and ways of life' (GLA, 2007: xiii). Distortions, exaggerations and oversimplifications regularly crept into the coverage, often expressed in a tone of language that was emotive, even alarmist. Amongst the Report's recommendations for change were the following:

\footnotetext{
* News organisations should review their coverage of issues and events involving Muslims and Islam, and should consider drawing up codes of professional conduct and style guides about use of terminology. Such codes of professional conduct should be based on their own best practice.

* News organisations should take measures, perhaps within the framework of positive action in equalities legislation, to recruit more journalists of Muslim heritage who can more accurately reflect the views and experiences of Muslim communities.

* News organisations should also consider how best to give Muslim staff appropriate professional support and to prevent them being pigeon-holed as specialists in minority issues rather than concerned with the full spectrum of an organisation's output.

* News organisations should treat seriously complaints relating to distorted coverage of Islam and Muslims in the media. (GLA, 2007: xiv-xv)
}

Underpinning each of these recommendations is a shared acknowledgment that anti-Muslim prejudice needs to be recognised and treated as a form of discrimination. Its harmful effects work in both directions. That is to say, prejudicial reporting is likely to 'produce provoke and increase feelings of insecurity, suspicion and anxiety amongst non-Muslims, 'while, at the same time, being 'likely to provoke feelings of insecurity, vulnerability and alienation amongst 
Muslims' (GLA, 2007; see also BAILEY, 2007; MELLOR, 2005; POOLE and RICHARDSON, 2006).

Laura Smith (2007), a Guardian journalist and one of the researchers for the Report (alongside her colleague Hugh Muir), found in the course of conducting her enquiry that basic journalistic standards were routinely compromised where news stories could be given a 'Muslim slant.' Regarding the difficulties of effecting change, however, she provides the following insight:

\begin{abstract}
Journalists, myself included, always get a bit snippy when they are criticised. Having worked for newspapers whose editorial line I might not have agreed with, I know the pressures journalists can be under to make a story work, regardless of the facts. But we as a profession need to take more responsibility for the stories we put into the public domain and the effect they have on wider society. True or not, these stories sink deep into public consciousness and can't help but influence the way people perceive each other. When, as in the case of stories involving Muslims, and before them black people and Jewish people, they are not balanced by more rounded coverage, the results can be deeply damaging (SMITH, 2007).
\end{abstract}

Journalist Angela Phillips (2007), commenting on the Report's findings and also her own related research, points out that 'journalists right across the press, whether on liberal newspapers or more conservative ones, have a lot of thinking to do about issues of representation.' New ways must be found to move beyond the discourse of 'tolerance' typically professed by newspapers in order to actually stop representing Muslims as 'visitors' in 'our' country, and thereby properly recognise everyone as fellow citizens with equal rights.

One example of the form such action can take is described by Harker (2010) with respect to changes underway at some British newspapers. Progress in improving the numbers of ethnic minority reporters employed has been slow, he points out, but is gradually getting better due to a number of strategies. He describes an initiative underway at The Guardian newspaper in London where a positive-action work placement programme - intended to attract racial minorities - is in operation. 'The large numbers of intelligent, enthusiastic, hardworking and motivated young men and women we've been able to bring into our office (and, yes, Muslim women too),' he observes, 'have given lie to that old media mantra, "but they don't apply"' (HARKER, 2010, p. 313). Further aspects of the plan of action to redress inequality include 'interview, recruitment and management training for editors and section heads; consultations 
with minority staff; advertising all entry-level jobs externally; and alerting minority journalists on our database when vacancies arise' (Ibid, p. 313). A crucial dimension to these efforts, he believes, is ethnic monitoring in order to measure relative progress. This commitment challenges the more typical view expressed by editors, namely that ethnicity is irrelevant in a performance-driven newsroom. In response, Harker asks:

without any supporting information, can newspapers really be sure that their recruitment is unbiased and that their editors see beyond the indeterminate cultural factors that so often lie behind selection decisions, such as: 'Do I feel comfortable with him?' 'Would she be a good laugh down the pub?' 'Would they fit in with our reporting team?' Journalists I contacted who work in some of these newsrooms reported that they are very white places indeed (HARKER, 2010, p. 314).

Enriching the diversity of the 'internal culture' of a news organization, it follows, is vitally important, and long overdue. 'One may find the occasional black or Asian journalist in a junior role on the commissioning desk, but rarely, if ever, in a position where they can make a decision on what goes into the next day's paper, let alone have any major long-term impact' (Ibid, s.p.) he adds. The fair treatment of employees within the organization is certain to translate into improvements in the quality of reporting (a further dimension requiring close monitoring), which will be of considerable social benefit to everyone.

At a time when so many news organizations are struggling to weather the global financial crisis, fears are growing that some will be forced to abandon their commitments to diversity. In the US, editor Mark Fitzgerald believes that there is a "pervasive feeling that the economy has pushed diversity goals not just to the back burner, but off the stove altogether' (EDITOR \& PUBLISHER, 2008). This retrenchment is being felt in the newsroom, but also in the failure to seize this moment as an opportunity to look beyond traditional (white, male) conceptions of the news consumer to engage a much wider audience in the community. 'If we don't think about these diverse audiences now, and work hard to get them, we may risk losing them forever,' executive editor Wanda Lloyd contends, before adding that 'diversity staffing and content go hand in hand. It you are committed to one, you are probably committed to both' (apud ANDERSON, 2008). 


\section{TOMORROW'S JOURNALISTS}

In light of this exploration, then, we may recognise the extent to which critical research is succeeding in documenting the gap between the rhetoric of journalistic identity and its lived materiality in everyday contexts. Pulitzer's intervention, as noted at the outset of this article, was about enhancing the relevance of journalistic identity to democratic values, the intention being to ensure that in the making of journalists, citizens would be produced. As such, it continues to this day to represent a clarion call for change in both the newsroom and the journalism classroom.

One way to engage with the forms of prejudice under scrutiny here, it follows, is to reinvigorate the journalist's identity as a citizen. 'The modern school of journalism begins its teaching from the premises of the profession it serves,' Carey (1978, p. 853) observed some three decades ago: 'In transmitting the language of professionalism it makes available to students a 'taken-for-granted world' of journalism that is rarely questioned or critically analyzed'. In considering the extent to which this holds true today, when long-established approaches to journalism education risk appearing anachronistic in the brave new world of the internet, it invites a welcome degree of self-reflexivity about all aspects of a university program's provision (see also FRANCISCATO, 2010; MOREIRA and HELAL, 2009). The pressures brought to bear upon journalism educators to make their curricula conform to the changing demands of the news industry must be met at a number of different levels, but especially with respect to the implications for teaching what counts as an appropriate identity in both personal and collective terms - for tomorrow's journalist. When familiar pedagogical approaches are threatening to unravel, it is vital that a renewed commitment to experiment and exploration be sustained.

The prestigious role once held to be the exclusive provenance of the professional journalist is being rapidly rewritten across the current mediascape, a process as far-reaching in its implications as it is inevitable. Any sense of complacency, particularly when ingrained in the norms and values of news reporting, must be recast before viable alternatives will begin to find their purchase. For journalists willing to participate in dialogue and debate about how best to define their identity in new, progressive ways, it may prove advantageous to begin not with the premises of a profession they seek to serve, but rather with their obligations to the diverse publics whose interests they claim to represent. 


\section{REFERENCES}

ALDRIDCE, M. The Paradigm Contingent Career? Women in regional newspaper Journalism. Sociological research online, vol. 6, no. 3, 2001.

ALLAN, S. News Culture, Third Edition. Maidenhead and New York: Open University Press, 2010a.

Professionalism: Journalism Without Professional Journalists? In STEINER, L. and CHRISTIANS, C. (Eds). Key Concepts in Critical Cultural Studies. Urbana: University of Illinois Press, 2010b. p. 145-157.

ASNE - American Society of Newspaper Editors. Newsroom Employment Census, 2008. Disponível em<www.asne.org/index.cfm?id=1138>.

ANDERSON, M.D. Minority Journalists Push Media to Maintain Diversity Commitment. issues in Higher education, 24 July, 2008.

BALLEY, O.G. (Ed). Transnational Lives and media: re-imagining Diasporas. London: Palgrave, 2007.

BECKER, B. and DE BUSTAMANTE, C.C. The past and the future of Brazilian television news. Journalism, Vol. 10(1): 45-68, 2009.

BOYLAN, J. Pulitzer's school. Columbia university's school of Journalism, 1903-2003. New York: Columbia university Press, 2003.

CANN, D.J. and MOHR, P.B. Journalist and Source Gender in Australian television news. Journal of Broadcasting \& electronic media, 45(1): 162-174, 2001.

CAREY, J.W. A Plea for the university tradition. Journalism Quarterly, Volume 55, Winter, 846-855, 1978.

CARTER, C., BRANSTON, G. and ALLAN, S. (Eds). News, Gender and Power. London and New York: Routledge, 1998.

CHAMBERS, D. and STEINER, L. The Changing Status of Women Journalists. In ALLAN, S (Ed). The Routledge Companion to News and Journalism. London and New York: Routledge, 2010.

CHAMBERS, D., STEINER, L. and FLEMING, C. Women and Journalism. London and New York: Routledge, 2004.

CHRISTMAS, L. Chaps of Both sexes? Women Decision-Makers in newspapers: Do they Make a Difference? Wiltshire: Women in Journalism in association with the Bt Forum, 1997.

COOPER, G. The hell of being white, middle-class and male. The Telegraph, 22 December, 2008. 
COURIC, K. A woman at the table. CBs Blogs, Couricand Co. 17 January, 2007.

DE ALBUQUERQUE, J. A. Another "Fourth Branch": Press and political culture in Brazil. Journalism, Vol. 6(4): 486-504, 2005.

DE BRUIN, M. and ROSS, K. Gender and Newsroom Cultures. Crestkill, NJ: Hampton Press, 2004.

DJERF-PIERRE, M. The Gender of Journalism. Nordicom Review, 81-104, 2007.

EDITOR \& PUBLISHER, s.I./USA, July, 25, 2008.

EVERBACH, T. The culture of a women-led newspaper. Journalism and mass Communication Quarterly, 83(3): 477-493, 2006.

FRANCISCATO, C.E. Tendencies in the development and consolidation of journalism research in Brazil. Communicatio: South African Journal for Communication Theory and research, Vol. 36(2):1 72 - 184, 2010.

GLA - Greater London authority. The search for common ground: Muslims, non-Muslims and the UK media. 2007. Disponível em <www. london.gov.uk>.

HARKER, J. Race and diversity in the news. In ALLAN, S (Ed). The Routledge Companion to News and Journalism. London and New York: Routledge, 2010.

HERSCOVITZ, H. G. Brazilian journalists' perceptions of media roles, ethics and foreign influences on Brazilian journalism. Journalism studies, 5: 1, 71-86, 2004. Disponível em< http://www.suttontrust.com/reports/ Journalists-backgrounds-final-report.pdf>

IREIAND, A. An Adventure with a Genius: recollections of Joseph Pulitzer. London: Lovat Dickson, 1938.

MARQUES DE MELO, J. Journalistic thinking: Brazil's modern tradition. Journalism, Vol. 10(1): 9-27, 2009.

MARTINEZ, M. The good listeners: Joseph Mitchell (u.S.), José Hamilton Ribeiro (Brazil) and literary Journalism. Brazilian Journalism research, Vol. 4(1): 121-139, 2008.

McGReGOR, J. The Pervasive Power of Man-made news. Pacific Journalism Review, 12(1): 21-34, 2006.

MELLOR, N. The making of Arab News. Lanham, MD: Rowman \& Littlefield, 2005.

MERIDIAN Star. Editorial: We honor and we apologize. Mississippi/USA, Meridien Star, jan. 18, 2009.

MOREIRA, S.V. and HELAL, C.L.R. Notes on media, journalism education and news organizations in Brazil. Journalism, Vol. 10(1): 91-107, 2009. 
NABJ - National Association of Black Journalists. Newspaper industry should Not Treat Diversity like a Passing Fad. Press release, 2008. Disponível em<www.nabj.org $>$.

NORTH, L. The Gendered Newsroom: How Journalists Experience the Changing World of Media, Creskill, NJ: Hampton, 2009.

PHILLIPS, A. Muslims and the media. The Guardian, 15 november, 2007.

POOLE, E. \& RICHARDSON, J. E. (Eds). Muslims and the News media. London: IB tauris, 2006.

PROJECT for Excellence in Journalism. The gender gap: women are still missing as sources for journalists. 23 May 2005. Disponível em< www. journalism.org/files/gender.pdf>.

PULLITZER, J. The School of Journalism in Columbia University, 2006 facsimile reproduction. The school of Journalism. Seattle: Inkling Books, 1904.

SEITZ, D.C. Joseph Pulitzer: His Life \& Letters. New York: Simon \& Schuster, 1924.

SMITH, I. You couldn't make it up. The Guardian, 15 november, 2007.

SUTTON TRUST. The Educational Backgrounds of Leading Journalists, June, 2006.

WALKER, T. Paxo must be undergoing a mid-life crisis. The Telegraph, 26 august, 2008.

WOMEN IN JOURNALISM. The Cheaper sex: How Women Lose Out in Journalism. London: WIJ Secretariat, 1998.

Stuart Allan is a professor in the School of Journalism, Media and Cultural Studies at Cardiff University, UK. Recent authored books include Citizen Witnessing: Revisioning Journalism in Times of Crisis (Polity Press, 2013). His edited collections include Citizen Journalism: Global Perspectives (co-edited with E. Thorsen, 2009), Rethinking Communication (2010) and The Routledge Companion to News and Journalism (2010). He is currently researching the use of digital images in news reports. 